\title{
Post-Hakikat Çağında Sosyal Medyada Yalan Haber ve Suriyeli Mülteciler Sorunu
}

\author{
Oğuzhan Taş \\ Doçent Doktor \\ tasoguzhan@gmail.com \\ Ankara Üniversitesi İletişim Fakültesi \\ Orcid: 0000-0001-5151-7155 \\ Tuğba Taş \\ Doçent Doktor \\ tugbakanli@yahoo.com \\ Ankara Üniversitesi Illetişim Fakültesi \\ Orcid: 0000-0003-0948-1683
}

\begin{abstract}
Fake News in Social Media and Syrian Refugee Crisis in the Post-truth Era

In this paper, we explore recent controversies on fake news and identify the circumstances by which the problem of fake news becomes current again. The status of truth in the ecology of news today is at the center of the discussion of fake news. Therefore, we decided to approach the problem in terms of social media reporting, user-generated contents, and post-truth politics. It is quite critical for us that the right populist movements turn false news into a political tactic to address the feelings and beliefs of citizens. In addition, we are trying to revise following questions: Which type of news would be rather considered as fake, how it is possible for fake news to spread so fast on social media and what types of fake news are more common. The last section of the article will be used to approach fake news about Syrian refugees in Turkey from a methodological perspective of multimodal textual analysis, in order to respond the ways in which discriminatory and hateful speeches propagate and legitimize so easily. As a conclusion, we suggest dealing with the fake news as a crucial component of political struggle over social reality instead of seeing the issue only regarding the media users' critical awareness.
\end{abstract}

keywords: fake news, social media, user-generated content, post-truth, Syrian refugees

DOI: 10.16878/gsuilet.500943 


\section{Résumé}

\section{Les infox à l'âge de Post-vérité et la Crise de Réfugiés Syriens}

L'objectif principal de cet article se résout dans la quête d'une réponse aux discussions sur les infox. Nous essayons de trouver les circonstances par lesquelles le problème des infox redevient actuel. Le statut de la vérité dans l'écologie des nouvelles est positionné au centre de la discussion des infox. Par conséquent, nous avons décidé d'approcher le problème par le journalisme sur les médias sociaux, par les contenus dérivé des utilisateurs, par le contexte du régime "post-vérité". Le fait que les mouvements droite-populistes transforment les infox à une tactique politique afin d'adresser les sentiments et la foi des citoyens, apparait assez critique pour nous. En outre, nous essayons de reconsidérer quels genres de nouvelles seraient plutôt considérées comme fausses, comment il serait possible pour les infox de propager rapidement sur les médias sociaux et quels sont les types des infox plus communs. La dernière section de l'article nous servira pour discuter du point de vue méthodologique de l'analyse textuelle multimodale, en nous concentrant sur les infox à propos des réfugiés Syriens en Turquie, les moyens selon lesquels les discours discriminatoires et contenant de la haine se propagent et se légitimisent si facilement. En conclusion, nous suggérons de considérer les infox comme un élément crucial de la lutte politique pour la réalité sociale plutôt que comme un problème de conscience critique des utilisateurs de médias.

mots clés: infox, les médias sociaux, les contenus dérivé des utilisateurs, post-vérité, Réfugiés Syriens 


\section{Öz}

Bu çalışmada, yalan haber tartışmasının hangi koşullar çerçevesinde yeniden güncellik kazandığı sorusuna yanıt arıyoruz. Günümüzün haber ekolojisinde hakikatin statüsü, yalan haber tartışmasının düğ̈̈m noktasında yer alıyor. Bu nedenle sorunu, sosyal medya haberciliği, kullanıcı türevli içerikler ve post-hakikat rejimi bağlamında değerlendiriyoruz. Sağ popülist hareketlerin yalan haberleri, yurttaşların duygu ve inançlarına hitap etmek için siyasal bir taktiğe dönüştürmesi bu açıdan oldukça kritik. Ayrıca, ne tür haberlerin yalan haber kategorisi içinde değerlendirildiği, yalan haberlerin sosyal medyada hızlı bir şekilde nasıl yayılabildiği ve yaygın karşılaşılan yalan haber türlerinin neler olduğu gibi literatüre özgü sorunları da gözden geçiriyoruz. Son bölümde ise, Türkiye'de yaşayan Suriyeli mültecilerle ilgili yapılan yalan haberlere çok modlu metin analizi çerçevesinden yaklaşarak, bu haberlerdeki ayrımcı ve nefret içeren söylemlerin nasıl kolaylıkla meşruiyet kazanıp yaygınlaştığı sorusuna yanıt arıyoruz. Sonuç olarak, yalan haberi bir eleştirel farkındalık sorununun ötesinde, sosyal gerçekliğin sınırları üzerinde yürütülen politik bir mücadelenin parçası olarak değerlendirmenin önemini vurguluyoruz.

anahtar sözcükler: yalan haber, sosyal medya, kullanıcı türevli içerik, post-hakikat, Suriyeli mülteciler 


\section{Giriş}

Kitlesel düzeyde yaygınlaşan "yalan haber"in (fake news) ${ }^{1}$ tarihi, en az medya tarihi kadar eskidir. Ticari gazetecilikteki en eski örneklerinden biri, dönemin metelik gazetesi New York Sun'ın 1835 yılında yayınladığı "Great Moon Hoax" serisidir (Allcott ve Gentzkow, 2017, s. 214). Ayda insan-yarasa melezi canlıların yaşadığı, hatta gelişmiş bir medeniyet bulunduğu iddiaları, illüstrasyonlar ve ayrıntılı betimlemelerle altı makalelik bir seri halinde dört gün boyunca yayınlanmış, haberlerdeki bilgiler düzmece bir şekilde, dönemin ünlü astronomlarından -olayla ilişkisi olmayan- Sör John Herschel'in elde ettiği öne sürülen kanıtlara dayandırılmıştır. Haberin ilk kez ticari bir metaya dönüşmeye başladığı bu erken dönemde New York Sun, "Ay'da hayat var" yalanıyla büyük bir tiraj artışı yakalamış ve bu yükselişini uzun süre devam ettirmiştir. Günümüzün bilimsel hakikat çerçevesinden bakıldığında düzmece olduğu aşikar olan ve inandırıcı bulunması ilk bakışta gazete okurlarının naifliği ya da eleştirel düşünme becerisinden yoksun olmasıyla ilişkilendirilebilecek bu durum, aslında dönemin koşulları gözden geçirildiğinde o kadar da şaşırtıcı değildir.

1830'lu yıllar, geçmişin, yanlı ve partizan ilan ettikleri habercilik geleneğinden kendilerini sıyırma çabası içindeki metelik gazetelerinin, gerçekleri halka ulaştırma ve onları aydınlatma nosyonuyla kendilerini tanımlamaya başladıkları bir dönemdir (Schudson, 1978, s. 14). Metelik gazetelerinin iddiasıyla, tarafgirlikten ve partizan çıkarlardan arınmış, olgular, kanıtlar ve bunlardan esinlenen illüstrasyonlarla desteklenen haber anlayışı, ucuz fiyatıyla halkın çoğunluğu için ilk kez erişilebilir hale gelen bu gazeteleri, dönemin hakikat rejiminin ayrıcalıklı mecralarından birine dönüștürmeye başlamıştır. Dahası, Ay'da hayat olup olmadığına dair iddia ve söylentiler o yıllarda Atlantik'in her iki yakasında oldukça yaygındır; kurmaca ya da gerçekçi pek çok popüler metnin konusunu oluşturmakta; astronomlar, Ay gözlemlerine dayandırdıkları pek çok spekülatif iddiayı bilimsel gerçekler olarak sunmaktadır. Bu toplumsal koşullar altında, New York Sun'ın yalan haberinin yarattığı etki kendi başına şaşırtıcı olmadığı gibi, asıl sorun okurların gerçeği yalandan ayırt etme becerisinden yoksun olmaları değildir. Hakikate ilişkin pek çok unsurun karmaşık bir etkileşime geçtiği toplumsal koşullar, bu haberin arka planındaki söylemsel gerçeklik evrenini oluşturmuştur. Nitekim New York Sun yaptığı bu haberlerin düzmece olduğunu hiç bir zaman açıkça yalanlamamış; popüler inançların gücüne güvenerek sessiz kalma taktiği izlemiştir. Böylelikle metelik gazetelerinin "gerçekler"le halkı aydınlatma nosyonunu sarsıntıya uğratmadan zirveye çıkmıştır.

Bilinmeyen gerçekliği temsil eden uzaylılar teması, yüz yıl sonra, 1938'de bu kez bir radyo temsilinin konusu olmuştur. 30 Ekim (Cadılar Bayramı'nın arifesi) günü, Mercury Tiyatrosu'nun H. G. Wells'in Dünyalar Savaşı kitabından radyo için yaptığı uyarlama CBS'te yayınlandığında, programı dinleyen binlerce

1 Fake news, "sahte haber", "uydurma haber" ya da "düzmece haber" terimleriyle de karşılanabiliyor. Ancak "yalan haber" en yaygın adlandırma şekli olduğu için biz de bu şekilde kullanıyoruz. 
kişi Marsılıarın istilasından kaçmak için panik halinde yollara saçılımışır (Scannell, 2007, s. 22). Bu bir yalan haber değildir. Geniş bir oyuncu ekibi eşliğinde temsili gerçekleştiren Orson Welles, programın başında ve sonunda bunun bir bayram hediyesi olduğunu açıkça seslendirmiştir. Ne var ki bu uyarılar sırasında radyo başında olmayan dinleyiciler, gerçek bir uzaylı istilasıyla karşı karşıya olduklarına kolayca inanabilmiştir. Temsilin inandırıcıığının altında yatan bu kez de, dinleyicilerin gerçeği kurmacadan ayırma konusundaki doğal yetersizliği değildir. Her ne kadar bu medya olayıyla ilgili geniş bir etki araştırması yürüten Hadley Cantril ve ekibi, düşük eğitimli dinleyicilerin "eleştirel beceri" yoksunluğuna vurgu yapmış olsalar $\mathrm{da}^{2}$, Orson Welles'in radyoya özgü, o dönem için yeni teknikleri başarıyla kullanmış olması güçlü bir gerçekçilik atmosferi yaratmıştır. Üstelik köklerinin bulunduğu Avrupa'da yayılmakta olan savaşla ilgili her gün bir son dakika haberiyle sarsılan Amerikalıların içinde bulunduğu "duygu durumu" (stimmung), onları her an yeni bir felaket beklentisine sokmuş, Hitler'in Avusturya'yı ilhakı sonrasında savaşın ABD'ye sıçraması endişesi daha da artmıştır (Scannell, 2007, s. 24) Varlıkları konusunda pek çok popüler ya da bilimsel söylentinin gündelik yaşama sızdığı Marslıların dünyayı istila etmesi için belki de bundan daha iyi bir zaman yoktur. Üstelik uzaylıların, işe dünya gücü ABD'den başlaması da akla yatkındır; tıpkı Hollywood yapımı pek çok bilimkurgu filminde gördüğümüz gibi.

Cantril ve ekibinin The Invasion from Mars (Mars İstilası, 1940) kitabında değinip geçtikleri ama eleştirel beceri yoksunluğu iddiasının gerisinde kalan tüm bu gelişmeler, radyo temsilinin yarattığı büyük paniğin altında yatan sebeplerdir. Medya metinlerinde hakikatin kendisi olarak temsil edilen olay ve olgulara ilişkin kavrayışımız toplumsal düşünme biçimlerimizin damgasını taşır. Sözgelimi Türkiye'de özel televizyon yayıncılığının ilk yıllarında karşılaştığımız Şok! gibi mizah programları, izleyiciler için yeni olan gizli kamera tekniklerini, helikopter çekimlerini, ses ve görüntü efektlerini kullanarak yarattıkları gerçekçilik atmosferiyle, tuvalet deliklerinden çıkarak insanlara saldıran yaratıklar, gündüz gözüyle görülen UFO'lar gibi mizah amacıyla üretilen kurmaca haberlerle benzer bir paniğe yol açabilmiştir.

Yukarıdaki örneklerden farklı olarak, olgusal gerçekliğe uygun haber yapmak ile toplumsal sorunlara dikkat çekmek gibi, ilk bakışta içsel bir çatışma barındırmayan gazetecilik nosyonları, kimi zaman yalan haber üretiminin arka planındaki ahlaki ikilemleri görünür hale getirmektedir. Bu bakımdan, gazetecilik etiği derslerinde sıkça sözü edilen Janet Cooke vakası, yalan haber üretiminin günümüzdeki bağlamıyla da yakından ilişkilidir. ${ }^{3}$

ABD'nin yoksul mahallelerindeki uyuşturucu ticaretinin yarattığı toplumsal sorunlara dikkat çekmek için çarpıcı bir haber peşinde koşan Washington Post muhabiri Janet Cooke, nihayet gazetenin 29 Eylül 1980 tarihli nüshasında "Jim-

2 Projenin başında Paul Lazarsfeld bulunuyordu, iddiayı ası öne süren kitabın ilgili bölümünü kaleme alan Herta Herzog'du.

3 Bkz. http://hoaxes.org/day/04_17_2001.html; http://jclass.umd.edu/archive/newshoax/casestudies/journalists/JourJim1.html. 
my'nin Dünyası" başlığı altında beş yaşında uyuşturucu bağımlısı olan bir çocuğun dokunaklı öyküsünü yayımlamıştır. Ancak Cooke, böyle bir çocuğun varlığına dair elde ettiği duyumları hiç bir zaman doğrulayamamıştır; öyküsünü anlattığı Jimmy, kurmaca bir karakterden ibarettir. Büyük ses getiren haber, Jimmy'e yardım eli uzatılabilmesi için Cooke'un üzerinde haber kaynağını açıklaması yönünde bir baskı yaratmış, uyuşturucu tacirlerinin hedef tahtası haline gelmemesi için haber kaynağını koruması gerektiğini savunan Cooke uzun süre bu taleplere direnmiştir. Ne var ki, Cooke'un bu haberle Pulitzer ödülü aldığı 13 Nisan 1981 günü muhabirin kendi geçmişiyle ilgili yalan söylediğini fark eden gazete yönetimi Jimmy'nin gerçekte yaşadığına dair bir kanıt sunmasını istemiştir. Cooke en sonunda, gerçekte böyle bir çocukla tanışmadığını itiraf etmek zorunda kalmış; gazeteden istifa edip ödülü iade etmiştir.

Janet Cooke sonraki açıklamalarında, çarpıcı bir haber yakalaması için bastıran editörleri suçlamıştır; öte yandan yalana sarılmış olsa bile uyuşturucu sorununa yönelik kamuoyu tepkisi yarattığı için memnundur. Şüphesiz, okurların duygularına hitap ederek dikkat çekme arzusu sadece bu habere özgü bir sorun değildir. Ne var ki, yakıcı bir toplumsal soruna dikkat çekmek için seçtiği yol, kurmaca bir mağduriyet öyküsüne dayanmaktadır. Olguların gücüne değil, kamunun duygusal tepkilerine güvenerek hareket etme dürtüsü, günümüz post-hakikat rejiminin de ayırıcı özelliğidir. Cooke'un seçimi, kendi kariyerine ve Washington Post'un güvenilirliğine zarar vermenin ötesinde, kamu görüşünün özgürce şekillenmesine yapılan tehlikeli bir müdahaledir. Olgusal gerçekliği esas alan haberler yoluyla, çevremizde olup bitenler hakkında bilgilenmek, bunlarla ilgili özgürce kanaat oluşturabilmek (Kuçuradi, 2009, s. 40), içinde yaşadığımız topluma ilişkin sorunlarla ilişkilenebilmenin ve hakikate yönelen ortak bir kavrayışa ulaşabilmenin önkoşuludur. Ne var ki bu tespitimiz, gazeteciliğin içinde yer aldığı toplumsal ve siyasal gerçekliğin tümüyle dışına çıkarak ona aşkın bir gözle bakabileceği anlamına gelmez. Nitekim yukarıda ele aldığımız tarihsel örnekler, gerçeklik iddiasındaki medya metinleri ve bunların inandırıcılığı arasındaki ilişkinin karmaşık bir hakikat sorununun parçası olduğunu göstermektedir. Janet Cooke vakasını ayırt edici kılan unsur ise, kamunun toplumsal ve siyasal hakikat arayışında gazeteciliğin kilit rolünü açığa çıkarması ve toplumsal sorumluluğun önemine vurgu yapmasıdır. Türkiye'de çok yakın tarihte yaşanan bir yalan haber vakası da, gazetecilerin hakikat arayışla ilişkilenme biçiminin ne tür demokratik tehditler yaratabildiğini göstermesi bakımından dikkat çekicidir.

13 Haziran 2013 günü Star gazetesinin baş sayfasında, gazeteci Elif Çakır'ın imzasıyla "Kadınlar küfrediyor, erkekler vuruyordu" (Çakır, 13 Haziran 2013) manşetiyle yayınlanan haber, sonraki günlerde önce "Kabataş Olayı" sonra "Kabataş Yalanı" olarak anılacak gelişmelerin düğüm noktasını oluşturmuştur. Yaşandığı ve kamera görüntülerinin bulunduğu iddia edilen olayı ilk gündeme getiren, dönemin başbakanı Recep Tayyip Erdoğan olmuştur. Erdoğan 7 Haziran 2013'teki grup toplantısında, Gezi Parkı protestocularından bir grubun, AKP'li bir belediye başkanının başörtülü gelinini yerlerde sürükleyerek darp ettiklerini duyurmuş, bu- 
nun üzerine olayla ilgili geniş bir tartışma başlamış, başbakanın iddiasını medya gündemine ilk taşıyan Yeni Şafak'tan Abdülkadir Selvi olmuştur (Selvi, 12 Haziran 2013). Buna karşılık, Elif Çakır'ın haberinin olayların düğüm noktasını oluşturmasının nedeni, iddia sahibi olan Zehra Develioğlu'yla yaptığı mülakattır (Çakır, 13 Haziran 2013). Develioğlu, arabasındaki bebeğiyle birlikte Kabataş'ta 70-100 kişilik bir protestocu grubun ortasında kalıp darp edildiğini, sözlü ve fiziksel tacize uğradığını detaylarıyla anlatmış; yayınlanan röportajın ardından pek çok köşe yazarı ve siyasetçi, bu beyanı esas alarak olaya ilişkin tepkilerini dile getirmişlerdir. AKP'li siyasetçiler ve partiyle olan yakınlığı bilinen gazeteciler, Develioğlu'nun iddiaları üzerinden Gezi protestocularına öfke ve nefretle dolu suçlamalar yönelterek konuyu politik propaganda aracına dönüştürmüşlerdir. Tüm bu söylemler, gerçekte ne yaşandığına dair iddia ve yorumlar dışında başka bir bilgiye erişme imkanı bulunmayan yurttaşlar arasında nesnel olgular değil, mevcut siyasal kanaatler ve duygusal tepkiler üzerinden bir ayrışma yaratmıştır. Röportajın yayınlanmasından bir ay sonra, Hürriyet yazarı İsmet Berkan, olaya ilişkin kamera görüntülerini izlediğini Twitter hesabından duyurarak yaşananları doğrulamıştır. Bu sırada görüntüler henüz yaygın dolaşıma girmiş durumda değildir. Buna karşıık Mehmet Metiner gibi bazı siyasetçiler de olayın doğruluğunu teyit eden görüntülere eriştiklerini iddia etmişlerdir.

Nihayet 13 Şubat 2014'te Kanal D televizyonu, saldırının gerçekleştiği iddia edilen gün, saat ve yere ilişkin MOBESE görüntülerini yayınlamış; görüntülerde bu tür bir saldırıyla ilişkisi olabilecek en ufak bir gelişme yaşanmadığı ortaya çıkmıştır. İddiaların somut bir temeli bulunmadığı ortaya çıktıktan sonra yazılanlar ise yukarıda sözünü ettiğimiz, gazetecilerin hakikatle ilişkilenme biçimleri bakımından ciddi sorunlar barındırmaktadır. Örneğin iddiaların gerçekliğini hararetle savunmuş olan Abdülkadir Selvi ve Elif Çakır, 15 Şubat 2014'te TimeTürk haber sitesine açıklamada bulunmuşlardır. Selvi, görüntülerin kendi başına bir şey ispatlamayacağını, 28 Şubat sürecinde de başörtülü kadınlara yönelik benzer saldırılar yapıldığını söylemiş; Çakır ise iddia sahibinin beyanının esas olması gerektiğinde ısrar ederek görüntülerin hükümeti yıpratma amacıyla gündeme getirildiğini savunmuştur (TimeTürk, 15 Şubat 2014). Bu açıklamalardaki dikkat çekici unsur, Ümit Kıvanç'ın Kabataş Olayı'na ilişkin detaylı değerlendirmesinde belirttiği gibi, her iki ismin de "olgusal düzeyden ilk fırsatta siyasete sıçramaları" ve görüntülerin somutluğuna karşılık siyaseten durdukları pozisyondan saldırının gerçekliği konusunda ısrarcı olmalarıdır (Kıvanç, 16 Şubat 2014).

Kabataş Olayı'nın açımlandığı tüm bu süreç, yalan haber üretiminin Türkiye'deki güncel görünüme daha yakından bakabilmemiz ve bunun demokrasi ve medyanın içinde bulunduğu hakikat kriziyle ilişkisini anlayabilmemiz için bize bir başlangıç noktası oluşturmuştur. Olgusal gerçekliğin ortada bir yalan haber olduğunu göstermesine karşın, tam da olguların kendisini geçersiz kılmaya dönük politik iddialarla yurttaş kanaatini manipüle etme çabası, bizi post-hakikat fenomeninin gazetecilik dünyasındaki gelişmelerle ilişkisi üzerine düşünmeye yöneltmiştir. 
Siyasal alandaki iddialar, spekülasyonlar, demeçler ile bunlara temel oluşturması beklenen olgular arasındaki bağın kopuşu, pekala siyasetin kendisine özgü bir sorunu olarak görülebilir. Nitekim, post-hakikat kavramı da esasen, olgusal olanı değersizleştiren siyasal eğilimleri tanımlamaktadır. Buna karşılık haber medyasının tüm bu eğilimlerle nasıl ilişkilendiği, bize göre, yurttaşların bilgilenme ve kanaat oluşturma hakkının sınırlandırıması ve yalan haberlere meşruiyet kazandıran bir toplumsal iklimin oluşması bakımından kritik bir öneme sahiptir. Medyaya yüklenen demokratik roller bağlamında, haberlerin hakikat arayışına katkıda bulunmasının gerekliliği, normatif düzeyde yaygın bir iddia olarak savunulmaya devam etmektedir. Yalan haber tartışması, tam da bu nedenle, gazeteciliğin demokratik süreçlerle olan ilişkisinde giderek derinleşen bir soruna dönüşmekte, post-hakikat, sosyal medya ve "kullanıcı türevli içerik"ler (user-generated content) bağlamında yeni popülist siyasal eğilimlerin ayrılmaz bir bileşeni olarak karşımıza çıkmaktadır.

Aşağıda ilkin, bu kritik bağlantının kuramsal hatlarını netleştirerek, yalan haber tartışmasının hem dünyada hem Türkiye'de neden böylesine güncellik kazandığını açıklamaya çalışıyoruz. Ardından ne tür haberlerin yalan haber kategorisi içinde değerlendirildiğini, yalan haberlerin sosyal medyada hızlı bir şekilde nasıl yayılabildiğini ve yaygın karşılaşılan yalan haber türlerinin neler olduğunu ele alıyoruz. Yazının son bölümünde ise yürütmekte olduğumuz tartışmayı, mülteci sorunuyla ilişkili bir çerçevede örneklendiriyoruz. Suriye'de süregiden savaşın dünya ölçeğinde yarattığı mülteci sorunu, sosyal medyadaki görünürlüğü ve ele alınma biçimi itibariyle, ırkçı-ayrımcı söylemlerin ve nefret söyleminin yoğun bir şekilde üretilip yaygınlaştırdığı bir zemin yaratmıştır. Bu zeminin yalan haberlerin üremesi için de elverişli olması pek şaşırtıcı olmamakla birlikte, Suriyeli mülteciler sorunu, yazıda geliştirdiğimiz sorunsalları somut gerçeklikle bağı içinde yorumlayabilmemiz için bize önemli veriler sunmaktadır.

Öncelikle, Suriyeli mültecilerle ilgili kullanıcı türevli yalan haberler tematik olarak ikiye ayrılmış, ardından temalar içinden seçilen haberler "çok modlu" (multimodal) metin analiziyle incelenmiştir. Çok modlu analizdeki çalışmaların çoğu, Ingiliz dilbilimci Michael Alexander Kirkwood Halliday'in her tür dilsel pratiğin sosyo-kültürel bağlamla etkileşimi içinde ele alındığı sosyal semiyotik dil kavrayışına dayanır (Paltridge, 2012, s. 170). Halliday'i takip eden Theo van Leeuwen (2011, s. 549-550), "çok modluluk" (multimodality) teriminin, "dil, imge, ses ve müzik gibi farklı semiyotik kaynakların çok modlu metinler içinde tümleşik kullanımına" işaret ettiğini ön sürer. van Leeuwen'e göre (2011) iletişimin kendisi çok modludur; sözlü iletişim, sözlü olmayan iletişimi hesaba katmadan ya da çağdaş yazıı dilin pek çok biçimi, aynı anda hem metni hem imgeyi dikkate almadan yeterince anlaşılamaz. Dolayısıyla çok modlu yaklaşım, iletişimin farklı modlarının bir arada nasıl anlam ürettiğine odaklanır. Görüntü ve metnin bir arada analiz edilmesi gerektiğini savunun van Leeuwen için Roland Barthes önemli bir yere sahiptir. Çünkü ona göre Barthes, sadece çok modlu iletişimin altında yatan genel prensiplere dikkat çekerek tüm iletişimsel modlara uygulanabilecek kavramsal bir çerçeve 
sunmakla kalmamış, aynı zamanda çok modlu metinlerde metin ve imgenin hangi yollarla tümleşik hale geldiğine ilişkin bir teori geliştirmiştir (van Leeuwen, 2011, s. 551). Barthes'ın, görüntünün anlamını sabitlemekte metnin üstlendiği işlevi tanımlamak için ortaya attığı "demirleme" (anchorage) kavramı burada sunduğumuz incelemede başat bir yere sahiptir. Aşağıda açıkladığımız üzere, Suriyeli mültecilere ilişkin yalan haberler genellikle imgelerin yanlış "demirlenmesi"yle oluşturulmaktadır. Ana hatlarını sunduğumuz bu metodolojik yaklaşım, Suriyeli mültecilere ilişkin yalan haberlerde metin ve imgenin tümleşik olarak nasıl anlam ürettiğine odaklanabilmemize ve anlamın bağlamsal niteliğine dikkat çekebilmemize olanak tanımaktadır.

\section{Yalan Haberin Üretiminin Güncel Bağlamı: Siyaset ve Medyanın Epis- temik Krizi}

Kamusal alanlarda bilhassa da medyada, siyasal tartışma ve katııımı sağlayacak toplumsal bilginin üretim koşullarındaki dönüşümün demokrasiyi epistemik bir krizle yüz yüze getirdiğini savunan Peter Dahlgren (2018, s. 1-6), yükselişe geçen günümüz sağ kanat popülizminin "doğru" bilginin görecelileştirildiği bu eğilimlerden fayda sağladığına dikkat çeker. Dahlgren'e göre (2018, s. 6), sağ kanat popülist hareketler halkın sistematik olarak aldatımasına dayalı taktiklerinde en büyük payı kurulu medya düzeni ve haber medyası pratiklerini etkilemeye ayırmaktadırlar. Bu siyasal taktikler, siyasetçilerin seri yalanlarından propagandaya, yalan haberlerin üretilmesinden bunların internet trolleriyle yaygınlaştırılmasına kadar hakikati saptırmanın çeşitli biçimlerini barındıır. Peki yalan haberlere siyasetçiler neden böylesine kilit bir taktiksel işlev atfetmektedir? Bu sorunun yanıtını Johan Farkas ve Jannick Schou'nun (2018) çalışmasında buluruz.

Yazarlara göre, yalan haber günümüzde politik mücadelenin temel kavramlarından biri haline gelmiş, siyasetçilerin rakiplerini itibarsızlaştırma ve gayri-meşru kılma çabalarında devreye soktukları bir hegemonya kurma aracına dönüşmüştür (Farkas ve Schou, 2018, s. 298-300). Bu rakipler doğrudan siyasal partiler olabileceği gibi, siyasetçilerin kendi ideolojik konumlarına karşıt tanımladıkları söylemler üreten kurum ve kuruluşlar da olabilmektedir. Örneğin Donald Trump, kendi seçim kampanyasında sıkça olgusal gerçekliğe aykırı ve yanlış yönlendirici bir söylem ürettiği, bu haliyle post-hakikat tartışmalarının başlıca akademik malzemesine dönüştüğü halde, New York Times, CNN ve Buzzfeed News gibi ana akım haber kuruluşlarını yalan haber üreterek kendisini itibarsızlaştırmaya çalıştıkları iddiasıyla hedef tahtasına koymuştur.

Bize göre, buradaki kritik nokta sadece siyasetçilerin bireysel ya da örgütsel söylemleri değil, bunların "yalan haber"e dönüşerek sosyal medyada yaygınlaşması ve post-hakikat rejimini yeniden üreten bir boyut kazanmasıdır. Oxford Dictionaries, 2016 yılının sözcüğü seçtiği post-hakikati, kamuoyunu şekillendirmekte duygulara ve inançlara seslenmenin nesnel gerçeklere göre daha etkili hale geldiği koşulları ifade eden bir kavram olarak tanımlamıştır (akt. Mclntyre, 
2018, s. 5). Lee Mclntyre'a göre (2018, s. xiv) post-hakikat fenomenini ayırt edici kılan, hakikate meydan okunması değil, Farkas ve Schou'nun (2018) da vurguladığı gibi, bu meydan okumanın politik üstünlük kurmanın bir aracına dönüşmesidir. Post-hakikat rejiminde kanıtlara dayalı olgular, bunların reddedildiği "alternatif gerçekler"le yer değiştirmekte; olguların geçerliliği yerini duygu ve inançların gücüne bırakmaktadır. Örneğin, kamusal kuruluşların ortaya koyduğu veriler tersini gösterse bile, siyasetçiler suç ve şiddetin artma eğiliminde olduğunu öne sürüp belli toplumsal grupları bunun faili olarak işaretleyebilmekte, kendilerine veriler hatırlatıldığında ise, halkın kendisini daha fazla tehdit altında hissettiği ve asıl önemli olanın halkın duyguları olduğu söyleyebilmektedir (Mclntyre, 2018, s. 2-4). Trump ve diğer Cumhuriyetçi adayların göçmen düşmanlığı tam olarak böyle bir eksende işlemiştir. Ya da Kabataş Olayı'nda gördüğümüz gibi mevcut görüntüler iddiaları desteklemediği ve elde başka bir doğrulayıcı veri bulunmadığı bir durumda, görüntülerin siyasi komplo maksadı taşıdığı söylenerek yurttaşlardan siyasi inançlarını önceleyerek olgulara itibar etmemeleri istenebilmektedir.

Dahlgren'e göre (2018, s. 6) karşı karşıya olduğumuz durum, sadece siyasal bir türbülans değil, sosyal gerçekliğe ilişkin en temel tanımların bile tartışmalı hale gelebildiği epistemik bir kakafoni yaratmaktadır. Dahası, sıradan gerçekliğe ilişkin temel bilgi yapılarını belirsiz hale getiren bu kakafoninin üretimi medya süreçlerinin ötesine uzanarak, uzmanlığa dayalı bilgi üreten üniversiteler, bilimsel araştırma kuruluşları ve okullar gibi kurumları da içine almıştır $(2018$, s. 6). Nitekim Dahlgren'in sınırlı bir siyasal sorundan fazlasına işaret eden ve rasyonel düşünme ölçütlerini (olgulara dayalı kanıtlar ve akla dayalı analiz) reddetme noktasına gelen epistemik kriz iddiasının ardında toplumsal bilgi üretimine yönelik bu yaygın eğilim bulunmaktadır.

Bu eğilimin gazetecilikle ilgili ayağı bizi sosyal medyanın günümüz haber üretim ve tüketim pratiklerinde edindiği ayrıcalıklı yeri yakından incelemeye yöneltmektedir. Çünkü anaakım gazeteciliğin günümüzde karşı karşıya kaldığı finansal baskılar, normatif konumundaki sarsılma ve yaşadığı okur kayıplarıyla belirginleşen krizi, sosyal medyanın geleneksel gazetecilik pratikleri üzerindeki etkileriyle, bir başka deyişle "sosyal medyanın yarattığı kendine özgü haber ekolojisiyle" (Newman vd., 2012) doğrudan bağlantılıdır.

Batı dünyasında yaklaşık 150 yıldır, haber ve reklam piyasasındaki belirleyici güç gazetelerde iken dijital teknoloji bu durumu geri dönülmez şekilde değiştirmiştir. Aidan White'a göre (2017, s. 16), reklam pastasındaki büyük payın internet medyasına kayışının haber odalarındaki özgül etkisi, araştırmacı gazeteciliğe ve özel haberlere ayrılan bütçelerde kesintiye gitmek şeklinde gerçekleşmiş; haber toplama ve yazma, özel uğraşlar için gereken maddi kaynakların yokluğunda, iktidar elitlerinin açıklamalarının takip edildiği masa başı bir faaliyete dönüşmüştür. Bu gelişmelerle eşzamanlı olarak, sosyal medya platformları, kullanıcıların haberleri takibinde artan ölçüde geleneksel medyanın yerini almaktadır. Örneğin Reuters Dijital Haber Raporu (2018) kapsamında Türkiye'de yapılan ankete göre, 
sosyal medya da dahil olmak üzere online kaynaklar yüzde 89'luk bir oranla en çok tercih edilen haber kaynağı olmuştur. Bunu yüzde 77 ile televizyon ve yüzde 47 ile yazılı basın takip etmektedir. Haber kaynağı olarak en çok kullanılan sosyal medya platformunun yüzde $51^{\prime}$ lik oranla Facebook olduğunu saptayan rapora göre onu, yüzde $41^{\prime}$ le YouTube, yüzde 35'le Twitter, yüzde 30'la WhatsApp, yüzde 24'le Instagram ve yüzde 9'la Facebook Messenger izlemektedir (Newman vd., 2018, s. 108).

Okurların haberleri sosyal medyadan takip etme yönündeki artan eğilimi, kullanılan algoritmik haber filtreleri yoluyla yalnızca kendi politik tutumlarıyla uyumlu türde haber ve değerlendirmelere erişimlerini kolaylaştırmaktadır (DahIgren, 2018, s. 6). Ne var ki bu kolaylık, paradoksal olarak, okurların sahip olduklarının dışında bakış açıları, dünya görüşleri ya da alternatif açıklamalardan daha az haberdar olmaları riskini de beraberinde getirmektedir. Çevrimiçi platformlarla ilgili en temel endişelerden biri, bu platformların benzer düşünen yurttaşların buluştuğu, karşıt görüşlerden yalıtımış "yankı odaları" (echo chambers) ya da "filtre balonları" (filter bubbles) yaratmasıdır (Allcott ve Gentzkow, 2017, s. 211). Bu konuda yapılan araştırmalar, örneğin Facebook kullanıcılarının, kendileriyle benzer düşüncelere sahip kişileri takip ettiklerini, böylece "haber kaynağı"nda (news feed) büyük ölçüde kendi görüşleriyle uyumlu haberlerle karşılaştıklarını göstermektedir (Shu vd., 2017, s. 25). Kiran Garimella vd.'Ierinin (2018) araştırması yankı odası etkisinin aynı şekilde Twitter'daki politik söylemlerin kutuplaşmasında da geçerli olduğunu ortaya koymuştur. Yankı odalarının yarattığı en önemli risklerden biri, işte bu kutuplaşma içinde eleştirel kanaat oluşturmaya yol açabilecek farklılıkların yalıtılmasıdır. Cass R. Sunstein (2018) haber ekolojisinin yerleşik bir unsuruna dönüşmüş olan yankı odalarının, kullanıcıların yalanlara daha kolay şekilde inanmalarına yol açabildiğine, hatta benzer görüşlü insanların birbirlerinin öfkesini yükseltmesiyle oluşan yankılanmanın, şiddet içeren aşırılıklara bile varabileceğine dikkat çekmiştir.

Propagandanın, nefret söyleminin ve salt kendisini olumlamaya dayalı post-hakikat siyasetinin yükselişini bu yeni kavramsal çerçevelerle ilişkili düşündüğ̈̈müzde, sosyal medyanın yalan haberler karşısındaki performansına odaklanmanın önemi daha belirgin hale gelmektedir. White'a göre (2017, s. 15) rakipsiz bir küresel güce dönüşmüş olan Facebook'un konumu bu bakımdan bilhassa kritiktir. Hunt Allcott ve Matthew Gentzkow'un (2017, s. 211) belirttiği gibi daha önceki medya teknolojilerinden çok farklı bir yapıya sahip olan Facebook gibi sosyal medya platformlarında içerik, ciddi bir üçüncü parti filtreleme ya da doğrulama yapılmadan, editoryal süreçten geçmeden kullanıcılar arasında aktarılabilmektedir. Örneğin Donald Trump'ın başkan seçilmesinden aylar önce Facebook, seçmen kanaatini manipüle etmeye dönük yalan ya da hileli haberlerin kendi platformlarında serbestçe yayılması konusunda herhangi bir girişimde bulunmadığı için ciddi eleştirilerle karşılaşmıştır (White, 2017, s. 15). Kurumun yetkilileri bu tür eleştiriler karşısında, Facebook'un bir haber organizasyonu olmadığını, yalnızca kullanıcıların (pek çok başka içeriğin yanı sıra) haber ve yorum paylaşmaları için bir 
platform sağladıklarını söylemiş olsalar da durum bundan çok daha karmaşıktır. Çünkü kullanıcı türevli içeriklerin asıl olarak sosyal medya için üretildiğini düşünürsek, sosyal medya platformlarının bu içeriklerin niteliğiyle ilgili hesapverebilir olmaları gerekmektedir.

Pek çok çalışmada, internet ve sosyal medya dolayımlı haberciliğin karşı karşıya olduğu en önemli problemlerden birinin enformasyon bolluğu olduğundan söz edilmektedir (Livingstone, 2004; Lievrouw, 2010; Ji vd. 2014). Geçmişteki enformasyon kıtlığı, ağlar ve akışlarla karakterize olan yeni teknolojik koşullarda yerini, sindirilip ayıklanması giderek zorlaşan bir enformasyon bombardımanına bırakmaktadır (Martin, 2017, s. 49-50). Kaynaklara daha kolay erişilebilmesi, olaylara ilişkin görsel-işitsel malzemelere ağ ortamında herkesin ulaşabilmesi ve sosyal medyanın sınırsız yorum yapmaya izin veren özellikleri, gazetecilerin doğru bilgiyi yanlış olandan ayırt etme konusundaki toplumsal sorumluluklarını daha kritik hale getirmektedir.

Bu noktada, enformasyon fazlalığına ilişkin değerlendirmeler, gazeteciliğin değişen koşullarını açıklamak bakımından önemli bir katkı sunmakla birlikte, bu fazlalığın yurttaşların özgür kanaat oluşturabilmesi bakımından olabildiğince çok alternatif bakış açısına erişmeye kendiliğinden yol açmayacağını belirtmek gerekir. Yukarıda söz ettiğimiz yankı odaları ve filtre balonları kendi içine kapanan sanal cemaatler yaratarak haber tüketim pratiklerini etkilemektedir. Daha da önemlisi habercilik faaliyetleri halen ulus-devletlerin yasal, iktisadi ve politik müdahalelerinin en yoğun görüldüğü alanlardan biridir. Özgür ve bağımsız haber üretiminin ve yurttaşların bunlara erişiminin sıkı denetim altına alındığı Rusya, Çin ve Türkiye gibi ülkelerde doğru ve güvenilir bilgiye ulaşabilmek ve yurttaşların kanaatlerini sosyal medya platformlarında rahatça ifade edebilmeleri giderek zorlaşmaktadır. Bilge Yeşil'e göre (2016, s. 138), "1980'lerden bu yana Türkiye'deki medya sistemini sarıp sarmalayan kayırmacılık, konglomeralaşma ve politizasyon AKP rejiminde daha da ağırlamıştır." Medya sahipliklerinin el değiştirmesi, gazetecilerin tutuklanması, muhalif sesleri susturmak amacıyla yayıncılık, internet ve basın kanunlarının istismar edilmesi, devlet kontrolündeki medya kuruluşlarına yapılan partizanca atamalar, internet ve sosyal medyaya ilişkin yasalardaki ağır hükümler ve sosyal medya paylaşımları nedeniyle yurttaşların gözaltına alınması/tutuklanması, Türkiye'de giderek sıkılaşan enformasyon denetiminin başlıca ayaklarını oluşturmaktadır (Yeşil, 2016, s. 138-139).

\section{Sosyal Medyada Yalan Haber: Tanımlamalar ve Sorunsallar}

Yalan haber terimi, günümüzde akademisyenlerin ve gazetecilerin diline yerleşmiş durumdadır. Ancak terim, akademik çalışmalarda birden fazla anlama gelecek şekilde kullanıldığı için, herkesin üzerinde uzlaştığı sabit bir tanımdan söz etmek zordur. Yalan haber kavramının akademik literatürde hangi anlamlarda kullanıldığına ilişkin araştırma yapan Edson Tandoc vd. (2017) kavramın, hiciv, parodi, uydurma haber, fotoğraf manipülasyonu, propaganda ve reklam anlamlarına 
gelecek şekilde kullanıldığını ortaya koymuşlardır. Terim günümüzdeki bazı haber kuruluşlarının eleştirel haberlerini itibarsızlaştırarak insanlarda şüphe uyandırmak amacıyla da kullanılmaktadır (Tandoc vd., 2017, s. 2, 5, 11). Daha önce sözünü ettiğimiz gibi, Donald Trump, muhalif haberler üreten ana akım medya için bu tabiri sıkça gündeme getirmiştir. 2017 yılında, 10 Ocak-2 Kasım tarihleri arasında sadece Twitter'da 146 defa ana akım medyayı, özellikle New York Times, Washington Post ve CNN'i yalan haber kaynağı olmakla itham etmiş̧tir (Hirst, 2017, s. 83-84).

Allcott ve Gentzkow (2017, s. 213) yalan haberi "yanlış olduğu bilinerek ve okurları yanlış yönlendirmek amacıyla kasıtlı olarak üretilen haber" olarak tanımlamışlardır. Bu tanıma göre, yalan haberin ayırıcı unsurları, haberin içerdiği enformasyonun yanlış olması ve bunun maksatlı olarak üretilip yaygınlaştııımasıdır. Böylelikle yazarlar, yalan haberin "kuzenleri" dedikleri, habercilik hatalarını, haberlerin kaynaklık etmediği söylentileri, komplo teorilerini, yanlış anlaşılma olasılığı olmayan hicivleri ve siyasetçilerin yanlış beyanlarını tanımın dışında bırakmışlardır (Allcott ve Gentzkow, 2017, s. 214).

Meselenin bütün bir enformasyon ekosistemiyle ilgili olduğunu söyleyen Claire Wardle ise (2017) yalan haber teriminin günümüz koşullarında yetersiz kaldığını savunarak bunun yerine "misenformasyon" ve "dezenformasyon" terimlerinin kullanılmasını önermiştir. Wardle (2017) misenformasyon ile dezenformasyon arasında yaptığı ayrımda, misenformasyonu yanlış bilginin "istenmeden paylaşılması", dezenformasyonu ise "sahte olduğu bilinen bilginin kasıtlı olarak yaratılması ve paylaşılması" olarak tanımlamıştır. Wardle'a göre (2017) misenformasyon ve dezenformasyon 7 kategoriden oluşmaktadır: yanlış bağlantı (başıı, görsel ya da alt yazının içeriği desteklememesi), yanlış bağlam (gerçek bir içeriğin yanlış bağlamsal bilgiyle paylaşılması), manipüle edilmiş içerik (gerçek imgelerin/ enformasyonun insanları kandırmak için manipüle edilmesi), yanıltıcı içerik (bir sorunu ya da kişiyi çerçevelemek için bilginin yanıltıcı kullanımı), taklitçi içerik (gerçek kaynakların taklit edilmesi), uydurma içerik (yanlış bilginin kandırma ve zarar verme amacıyla yayılması), hiciv/parodi (kandırma ihtimali olan ama zarar verme amaçlı olmayan içerik). Wardle (2017) hiciv ve parodiyi dezenformasyon türleri içine dahil etmesiyle Allcott ve Gentzkow'dan ayrılsa da onun dezenformasyon tanımı, Allcott ve Gentzkow'un yalan haber tanımıyla temelde aynıdır.

Sosyal medyada yalan haber üretiminin iki ana motivasyonla yapıldığı söylenebilir: finansal ve ideolojik. Finansal anlamda, viral olan yalan hikayeler, içerik üreticileri için tıklanma sayıları üzerinden reklam gelirlerine dönüştürülebilir. Örneğin 2016 ABD başkanlık seçimleri sırasında Makedonya'daki gençler, Trump ve Clinton için ürettikleri hikayelerle on binlerce dolar kazanmışlardır. İdeolojik düzlemde ise kişi ve gruplar belirli fikirleri veya siyasi hareketleri desteklemek için yalan haber üretmektedir (Allcott ve Gentzkow, 2017, s. 217). Ayrıca gazetecileri ve kullanıcıları yanıltmak amacıyla hükümetlerin tasarladığı yalan haberler de temelde ideolojik bir motivasyona sahiptir (Hirst, 2011, s. 37). 
Yalan haberler hangi kaynaklardan yayılmaktadır? Bunun için uzun bir liste yapmak gerekir. Profesyonel medya kuruluşlarının dışında, kullanıcıların işin başında olduğu kaynaklar arasında, gerçek haber sitelerinin hem biçimsel özelliklerini hem de metinlerdeki sözdizimsel özellikleri taklit eden web siteleri; kullanıcı ismi, logo ve metin yapılarıyla ciddi ve güvenilir haber kuruluşu havası yaratan kullanıcı hesapları; resmi ya da yetkili bir kuruluş havası verilen web sayfaları ve nihayet tekil kişiler bulunmaktadır. Yalan haberler, kolaylıkla izi sürülüp hakkında ayrıntılı bilgi edinilemeyen bu tür kaynaklarca üretildiği ve haberler güçlü bir gerçeklik etkisi yarattığı için okurlar bunları doğrulama konusunda zorluk çekerler. Dahası sosyal medyada dolaşıma giren böylesi haberler, tanıyıp güvendiğimiz kişi ve grupların dolayımıyla erişilir hale geldiğinde kolayca meşru bir statü kazanabilirler (Tandoc vd., 2017, s. 7).

Sosyal medya kullanıcıları kimi zaman gerçek kişiler bile olmayabilir. Örneğin "sosyal botlar" (socialbots), bir bilgisayar yazılımı tarafından kontrol edilen ve otomatik mesaj üretebilen sosyal medya hesaplarıdır; bunların bazıları yalan haber üretip yaymak amacıyla özel olarak tasarlanmaktadır. Teknolojik bakımdan giderek sofistike bir nitelik kazandırılan botlar, gerçek bir kullanıcı gibi karmaşık etkileşimlere girebildiği, örneğin sohbet edip yorum yapabildiği, sorulara yanıt verebildiği ölçüde gerçek bir kullanıcıdan ayırt edilemez duruma gelmektedir. Bu konuda yapılan araştırmalar, sosyal botların 2016 ABD başkanlık seçimlerinin çevrimiçi tartışmalarını büyük ölçüde çarpıttığını göstermiştir (Shu vd., 2017, s. 25; Ferrara vd., 2016, s. 99). Seçim sırasında ve sonrasında, 400 bin iddiayı yaymış olan 14 milyon Twitter mesajını inceleyen Shao vd. (2017) sosyal botların yaIan haberlerin yayılmasında asli bir rol oynadığını ortaya koymuşlardır. İnsan ve bot arası bir tür olan cyborg kullanıcılar da otomatik aktiviteleri insan girdisiyle harmanlayarak sahte haberleri yayabilmektedir. Cyborg hesapların kayıt işlemleri, kamufle edilmek amacıyla gerçek kullanıcılar tarafından yapılmakta ama sosyal medyadaki faaliyetleri gerçekleştirmek için otomatik programlar kullanılmaktadır (Shu vd., 2017, s. 25).

Yalan haberin en önemli "destekçileri" görüntülerdir. Bir başka deyişle, yanlış bilgiler içeren haber metinlerine gerçeklik statüsü kazandırmak için sıkça fotoğraf ve video manipülasyonuna başvurulur, haberin gerçekliği tartışma yarattığında hemen elde edilen görüntülerden söz edilir. Bu nedenle yanlış haber üretiminde fotoğraf ve videoların nasıl kullanıldığını detaylandırmamız gerekir.

Fotoğraf manipülasyonu pek çok yolla yapılabilir: Farklı fotoğrafların birleştirilmesi veya fotoğrafa ekleme yapılması; fotoğraftaki çeşitli unsurların silinmesi veya kesilerek çerçeve dışı bırakılması; fotoğrafın belirli kısımlarının rötuş yapılarak belirgin hale getirilmesi veya geri plana itilmesi ve fotoğrafın haberin bağlamıyla ilgisiz şekilde kullanılması en sık karşılaşılan uygulamalardır. Fotoğraf tarihine baktığımızda aslında bu tür uygulamaların her zaman gündemde olduğunu görürüz. Örneğin, dönemin serbest foto-muhabirlerinden Horace Nicholls'ın, 1906 yılında çektiği ünlü Derby Day fotoğrafında, kalabalığı artırmak için fotoğrafta şemsiye 
tutan insanları klonlayarak fotoğrafın boş bölgelerine taşıması (Fineman, 2012, s. 50), günümüzle bağlantısı bakımından da ilginç bir örnektir. Bilindiği üzere, kongre ve mitinglere katılanların sayısını daha kabarık gösterebilmek, coşkulu, büyük bir kalabalığın etkinlikte hazır bulunduğuna kanıt oluşturabilmek için dijital görüntü klonlama teknikleri günümüzde sıkça kullanılmakta ve katıımcı sayıları hakkında büyük tartışmalara konu olabilmektedir.

Analog ve dijital dönem arasında fotoğraf manipülasyonu bağlamında bir süreklilik olduğu söylenebilir. Ancak dijital dönemde bu tür müdahaleler hem çok daha kısa sürede hem de gerçeğe benzerlik bakımından çok daha etkili şekilde yapılabilmektedir (Lister vd, 2019, s. 18). Bu nedenle uluslararası haber kuruluşları, dijital görüntülere teknik olarak ne ölçüde müdahale edilebileceği konusunda kimi ölçütler geliştirme gereği duymaktadır. Sözgelimi Reuters, görüntünün tonunu ve rengini dengeleme gibi teknik iyileştirmelere izin verirken, görüntüye bakanları yanıltabilecek düzeydeki müdahaleleri yasaklamıştır. Görüntü unsurları üzerinde ekleme, çıkarma, gizleme yapmanın yanı sıra bağlamı farkılıştırabilecek düzeydeki ton ve renk müdahaleleri de buna dahildir (Tandoc vd., 2017, s. 8). 2006 yılında Adnan Hajj'ın Beyrut'taki İsrail hava saldırısının etkisini daha yoğun şekilde hissettirebilmek için binadan çıkan dumanları klonlayarak çoğalttığının anlaşıması üzerine, fotoğrafı servis eden Reuters özür dilemek zorunda kalmış ve fotoğrafçıyla ilişkisini sonlandırmıştır (Reuters, 2007). Hajj'ın yaptığı beceriksiz klonlama, çıplak gözle kolayca anlaşılabilir niteliktedir; buna karşıık, dijital manipülasyon konusunda uzmanlaşmış kişilerin yaptıkları müdahaleleri ayırt edebilmek ancak teknik incelemeyle mümkün olabildiği için görüntülere bakanları kolayca aldatabilmektedir. Üstelik Tandoc vd.lerinin belirttiği gibi (2017, s. 9), Reuters'ın devreye soktuğu türde kontrol mekanizmalarının sosyal medyadaki paylaşım kurallarında ve filtreleme mekanizmalarında karşılığı yoktur. Bu durum görüntü manipülasyonuna dayalı yalan haberlerin yaygınlaştıııması için sosyal medyayı elverişli bir platform haline getirmektedir. Ayrıca yalan haberler yalnızca profesyonel kişi ve kuruluşlar tarafından değil, bizzat kullanıcılar tarafından üretilip paylaşılabildiği için, güncel koşullarda yalan haber sorununu profesyonel habercilik tartışmasının ötesinde kullanıcı türevli içeriklerle ilişkisi içinde ele almak gerekmektedir.

Yukarıda söylediğimiz gibi görüntü manipülasyonunun günümüzde en sık görülen biçimlerinden biri, fotoğraf ve videoların yanlış bağlamda kullanılmasıdır. Yanlış bağlam, görüntüyle birlikte kullanılan bir yazılı metin aracılığıyla oluşturulur. Barthes'ın (2003) söylediği gibi imgeler çok anlamlı olduğu için metin bir "demirleme" işlevi görür; belirsizliği ortadan kaldırmak, görüntünün anlamını sabitlemek ve imgeye bakan kişiyi yönlendirmek için kullanılır. Barthes'a göre (2003, s. 117118) metin "bu nedir?" sorusunu cevaplar ve sahnenin tanımlanmasına yardımcı olur. Haber metinleri, imge ve yazı arasındaki bu sabitlemenin mutlak şekilde yapılandırılmaya çalışıldığı metinlerdir. Ancak yalan haberde görüntüler metinle yanlış bir bağlama "demirlenmektedir". Görüntülerin üzerine düzmece metinler yazarak, görüntüleri belli bir anlamda sabitlemeye çalışan bu tür içerikler sosyal medyada oldukça yaygındır. Tam metinli bir haberden farkını ortaya koyabilmek için, Martin 
Hirst (2011, s. 110) bunları "kullanıcı türevli haber benzeri içerik" (user-generated news-like content) olarak adlandırmıştır. Bu içeriklerin çok ses getiren bir örneği, yine 2016 Amerikan başkanlık seçimlerinin kampanya sürecinde gündeme gelmiştir. Twitter'da 400 takipçisi olan bir kullanıcı, çektiği 3 fotoğrafı Trump karşıtı protestocuları taşıması için tutulmuş otobüsleri gösterdiğini iddiasıyla paylaşmıştır. Fotoğraflar kısa süre sonra viral bir hızla yayılarak Reddit, Facebook ve sağ eğilimli web sitelerinde paylaşılmıştır. Toplam paylaşım sayısı 370 binin üzerindedir. Otobüsler gerçektir ama insanları, seçimle tamamen ilgisiz bir toplantıya taşımaktadır. Diğer bir deyişle fotoğraf olgulara dayanmaktadır, ama uydurulmuş bir hikayeyi desteklemek için kötüye kullanılmıştır (Tandoc vd., 2017, s. 9).

Sosyal medya platformlarındaki kullanıcılar, kampanya otobüsleri örneğinde olduğu gibi, sadece var olan haberleri paylaşmakla kalmayıp kendileri de haber benzeri içerikler üretmektedir. Herhangi bir başka haberle bağlantısı olmayan, doğrudan kullanıcıların ya da grupların oluşturduğu içeriklerde haber benzeri sözdizimi, "tıklama tuzağı" (clickbait) ve "kanıt" görüntüler kullanılarak gerçeklik etkisi yaratılmakta, beğeniler ve yeniden paylaşımlarla bu içerikler kısa zamanda geniş bir kullanıcı kitlesine ulaşabilmektedir. Bu nedenle sosyal medya platformlarında kullanıcılar tarafından üretilen, "yanlış olduğu bilinerek ve okurları yanlış yönlendirmek amacıyla kasıtlı olarak üretilen" haber benzeri içerikler de yalan haber kapsamında değerlendirilmelidir. Bu bakımdan sosyal medya ekolojisi, profesyonel süreçlerin çıktısı olan haberler ile bu niteliği taşımayan haber benzeri içerikler arasındaki sınırın bulanıklaşmasında pay sahibidir. Bu sınıın bulanıklaşması, kullanıcıların neyin doğru, neyin yanlış olabileceğine dair referans çerçevelerini sarstığı ölçüde, yanlış bilgilere dayanan içeriklerin hızla türeyip yaygınlaşmasına elverişli bir ekosistem yaratmaktadır.

\section{Suriyeli Mültecilerle İIgili Yalan Haberler: İddialar ve Gerçekler}

Reuters Dijital Haber Raporu'nda (2018) Türkiye'yle ilgili dikkat çekici verilerden biri yalan haberlere ilişkindir. Anket uygulanan Türkiyeli kullanıcıların yüzde 49'u bir önceki hafta yalan habere maruz kaldıklarını söylemişlerdir. Örneklemde yer alan 37 ülke arasında en yüksek oran Türkiye'ye aittir (Fletcher, 2018, s. 39). Bu çarpıcı veri, yalan haberlerin Türkiye'deki habercilik ortamının en öncelikli sorunlarından biri olarak ele alınması gerektiğine işaret etmektedir. İdeolojik motivasyonla üretilerek yaygınlaştırılan yalan haberlerin, yankı odası etkisiyle toplumsal gerçekliğe ilişkin çarpıtılmış bir manzara oluşturabilme ihtimalleri söz konusu oran dikkate alındığında kaygı vericidir. Bilhassa belli kişi ve gruplara yönelik dışlayıcı söylemler üreten yalan haberlerin, mevcut olumsuz kanaatleri veya nefret duygularını pekiştirmek gibi bir tehlike barındırabileceğini Suriyeli mültecilerle ilgili yapılan haberler üzerinden takip etmek mümkündür.

Türkiye' de faaliyet gösteren bir doğrulama platformu olan teyit.org (2017), Suriyeli mülteciler hakkında 2017 ve 2018 yıllarında yayınlanan on dört yalan ha- 
ber tespit etmiştir. ${ }^{4}$ Bunların biri haricinde hepsi sosyal medyada yaygın dolaşıma girmiştir. Haberlerin on birinde görüntü kullanılmış; üçünde videoya, beşinde fotoğrafa uydurma bir hikaye yazılmış, bir fotoğraf dijital ortamda manipüle edilmiştir. Haberlerin biri haricinde hepsi kullanıcı türevli içeriktir. Suriyeli mültecilerle ilgili üretilen bu haberleri iki ana temaya ayırabiliriz. IIlkinde mülteciler yurttaşların aleyhine sonuçlar doğuracak şekilde ekonomik ve sosyal ayrıcalıklara erişen bir grup olarak ele alınırken, ikincisinde şiddet eylemleriyle ilişkilendirilerek kamu güvenliğine tehdit unsuru olarak tanımlanmaktadır.

Illk temayı oluşturan haberler, Suriyeli mültecilerin, kendilerine sağlanan ekonomik ve sosyal ayrıcalıklar sayesinde, sıradan yurttaşlardan esirgenen düzeyde bir refaha kavuştukları kanaatini yaygınlaştırma amacına yöneliktir. "Suriyelilere alışverişlerde yüzde 50 indirim sağlayan Ak Kart verildiği" (Özer, 07 Şubat 2017), "Konya Büyükşehir Belediyesi'nin Suriyelilere maaş bağladığı" (Özer, 14 Şubat 2017), "Suriyeliler[in] maaşlarını almak için PTT önünde kuyruğa gir[diği]" (Özer, 09 Mart 2017), "Gaziantep'te Suriyelilerin vatandaşlık için kuyruğa girdiği" (Foça, 28 Mart 2017), "Suriyelilerin istedikleri üniversiteye hiçbir koşul olmadan girdikleri" (Özer, 06 Mart 2017), "131 bin 746 Suriyelinin üniversiteye yerleştirildiği" (Arabacı, 18 Ağustos 2017) şeklindeki iddiaların gerçekle bağı olmadığı yine teyit.org tarafından tespit edilmiştir.

Bu iddialarda kullanılan "Suriyeliler" sözcüğü ile Suriyeli mültecilerin homojen ve işgalci bir topluluk olduğuna yönelik bir izlenim yaratılmaya çalışıldığı söylenebilir. David Machin'in belirttiği gibi pek çok çalışma "dilin dünyayı ideolojik olarak inşa ettiğini" ortaya koymuştur. Bu nedenle tanımlar üzerine daima toplumsal bir mücadele vardır (Machin, 2007, s. xiii). Bir toplumsal grubu tanımlarken seçilen sözcükler, söz konusu grupla ilgili toplumsal gerçekliğe ilişkin ideolojik söylem üretip, o grubu belirli bir konuma sabitleyebilir. Machin'in söylediği gibi imgeler de tıpkı dil gibi ideolojiktir (Machin, 2007, s. xiii). Suriyeli mültecilerle ilgili ilk temayı oluşturan yalan haberlerde, eldeki görüntüleri, düzmece iddialarla birleştirerek habere dönüştürme taktiği karşımıza çıkar. Bu görüntüler tıpkı "Suriyeliler" sözcügü gibi Suriyeli mültecileri homojenleştirmekte ve basmakalıp yargılar içinde temsil etmektedir. Van Leeuwen (2004, s. 96) insanları bireyler olarak değil gruplar halinde, özellikle de benzer pozlar ya da benzer eylemler içinde tasvir etmenin stereotipleştirmeye ve "hepsi aynı" tarzında bir genelleştirmeye neden olabileceğini söylemiştir. "Suriyelilerin Konya'da maaş kuyruğuna girdiği" iddiasıyla paylaşılan dört fotoğrafta, üzerinde "Sosyal Kart Bürosu" yazan bir binanın önünde toplanmış insanlar benzer bedensel duruşlarla, aynı tarafa yönelmiş olarak durmaktadırlar. Yüzleri binaya dönük olan insanların sadece sırtlarını görürüz. Van Leeuwen (2004, s. 96) ayrıca insanları uzak mesafeden gösteren genel plan çekimlerde insanların bireysel özelliklerini daha az ayırt edebildiğimizi, bu nedenle bu tür çekimlerin insanların bireyselliklerini azaltarak onları belirli bir tipe indirgeyebileceğini söylemiştir. Bu bağlamda söz konusu yalan haberde kullanılan,

4 Çalışmayı kaleme aldığımız sırada ulaştığımız bu rakam, teyit.org'un sürdürmekte olduğu haber taramasıyla aynı bağlantı üzerinden güncellenip duyurulmaktadır. Bakınız, teyit.org (2017). 
Suriyeli mültecileri bir grup olarak gösteren genel plan çekimlerin onları bireyselleştirmemizi engellediğini söyleyebiliriz. Van Leeuwen'in belirttiği gibi (2004, s. 96) fotoğrafla birlikte kullanılan sözcükler de tasvir edilen kişiyi isimlendirebilir ya da bir tür olarak tanımlayabilir. Bizim örneğimizde fotoğrafta görülen insanlar "Suriyeliler" olarak, bir türün tipik örnekleri olarak tanımlanmıştır. Fotoğrafla birlikte kullanılan yazı fotoğrafın anlamını sabitlemiş, fotoğraf ve yazı bir arada bir tür olarak Suriyeli mültecilerin hak etmedikleri ayrıcalıklardan faydalandıklarına ilişkin bir söylem üretmiştir.

Bu tema içindeki haberlerden biri, gazetecilerin bu tür haberleri doğrulamadan kullanmalarının da bir örneğidir. Gaziantep'te "Suriyelilerin vatandaşlık için kuyruğa girdiği" iddiasıyla paylaşılan fotoğrafta, mülteciler aslında Nüfus Müdürlüğü önünde yardım kuruluşlarından destek alabilmek için adres bildiriminde bulunmaktadır. Bu yalan haberi, Birgün yazarı Erk Acarer bireysel Twitter hesabından paylaşmıştır. Günümüzde gazeteciler, sosyal medyayı sadece haberlerini duyurmak için değil, aynı zamanda bir haber kaynağı olarak da kullanmaktadır. Ne var ki doğrulanmamış iddialar, gazeteciler tarafından yaygınlaştırıldığı ölçüde meşruiyet kazanıp, dezenformasyonun gerçeklik gücünü pekiştirmektedir.

İkinci temayı oluşturan haberler, "Suriyelinin bir doktoru dövdüğ̈̈" (Çavuş, 12 Eylül 2017), "Suriye'de organ mafyasının bir çocuğu kaçırdığı" (Çavuş, 15 Mayıs 2017), "Iki Suriyelinin Bursa'da bir kadını kaçırıp tecavüz ettiği" (Çavuş, 9 Eylül 2017), "Bursa'da yaşayan Suriyelilerin bir atı kafasına vurarak öldürdüğ̈̈" (Foça, 25 Ağustos 2017), "Suriyelilerin Türkiye halkının dinden kopuk yaşadığını söyleyerek yürüyüş yaptığı" (Özer, 09 Haziran 2017) ve "Suriyelilerin Türkiye'ye gelen Afgan mültecileri protesto ettiği" (Çavuş, 11 Nisan 2018) şeklinde iddialar barındırır. Haberlerin bir kısmı, şiddet eylemlerinin faili olarak gösterilen Suriyeli mültecilerin Türkiye'deki varlığına karşı okurlarda olumsuz bir duygusal izlenim yaratma peşindedir. Son iki haber ise, Suriyelilerin ne "ev sahiplerine", ne de "diğer misafirlere" hoşgörü gösterdiğini, tersine ya onları dinsizlikle suçladığı ya da kapı dışarı etmek istediğini ima eder.

Bu örnekler, kişilerin aynı grup içinde değil, tekil olarak temsil edilmelerinin de her zaman olumlu bir anlam üretmeyebileceğini gösterir. Örneğin "TC halkının dinden kopuk yaşadığını ve açık seçik giyinerek Suriyeli gençleri tahrik ettiğini belirten kalabalık Suriyeli gurup Gaziantep Valiliği'ne yürüdü" yazısıyla birlikte yakın plan çekimle iki erkeğin gösterildiği bir fotoğraf kullanılmıştır. Ancak bu fotoğrafta iki erkek, bireysel özelliklerini öne çıkaracak şekilde değil, van Leeuwen'in (2004, s. 95) kavramıyla "sosyal bir tür"ün örneği olarak temsil edilmişlerdir. Tipikleştirmenin ya da belirli bir türün örneği olarak temsil etmenin görsel stereotiplerin kullanımı yoluyla gerçekleştiğini söyleyen van Leeuwen'e göre, bunun yolu elbise, saç modeli gibi kültürel simgeler olabileceği gibi fizyonomik simgeler de olabilir. Bizim örneğimizde ikisinin bir arada kullanıldığını görmekteyiz. Fotoğrafta iki erkeğin başındaki kefiyeler kültürel simgeler, erkeklerin koyu ten renkleri ise fizyonomik simgelerdir. Hem kültürel hem de fizyonomik simgelerle işaretlenen 
erkeklerin beden dillerine ve yüz ifadelerine baktığımızda yumruklarının havada ve ağızlarının bir şey haykırır gibi açık olduğunu, öfkeli bir ifadeyle gözlerini belirli bir noktaya dikmiş olduklarını görürüz. Tüm bu nitelikler Suriyeli mültecilerin "saldırgan" olduklarına ilişkin bir söylem üretmektedir. Fotoğrafta yakın plan çekim kullanılmış olmakla birlikte çerçevenin sağ kenarından giren, kime ait olduğunu görmediğimiz yumruklar ve arka planda net alanın dışında kalan başka bir erkeğin yüzü ön plandaki iki erkeğin halihazırda bir kalabalığın parçası olduğu izlenimi uyandırmaktadır. Bu bakımdan fotoğraftaki iki erkeğin stereotipleştirilmiş biçimde temsil edildiklerini söyleyebiliriz. Fotoğrafla birlikte kullanılan yazıdaki "Suriyeli gurup" ifadesi de bu iddiamızı desteklemektedir.

Teyit.org'un incelemelerinden, bu haberin ve ikinci temayı oluşturan diğer haberlerin tamamında, bir başka olaya ilişkin video veya fotoğraf üzerine uydurma hikayeler yazıldığı anlaşımaktadır. Ne var ki haberler yanlış yönlendirme konusunda bir hayli etkili olmuş, bir anlamda amaçlarına ulaşmışlardır. Örneğin Suriyeli mültecinin bir doktoru dövdügü iddiasıyla paylaşılan video, teyit.org ekran görüntüsü aldığı anda bile, 1 milyon 300 bin kere izlenmiş, 38 bin 317 kez yeniden paylaşılmıştır. Videonun aslında, Rusya'nın Veliky Novgorod şehrinde 23 Şubat 2017 'de gerçekleşen bir olaya ait olduğu sonradan anlaşılmıştır. Aynı video, Fransa ve İspanya'da mültecileri hedef göstermek için de kullanılmıştır. Suriyelilerin bir atın kafasına vurarak öldürdüğü iddiasıyla yapılan video paylaşım ise teyit.org ekran görüntüsü aldığı sırada 655 bin kez görüntülenmiş, neredeyse 20 bin kez paylaşılmışır. Suriye'de organ mafyasının bir çocuğu kaçırdığı iddiasıyla montajlanarak paylaşılan videoyu ise Birleşmiş Milletler İnsani İşler Koordinasyon Ofisi (OCHA) partneri olan Syria Charity isimli dernek yalanlamış ve videodaki küçük kızın hayatta olduğunu gösteren bir video paylaşmıştır (Çavuş, 15 Mayıs 2017). Suriyeli iki kişinin Bursa'da bir kadını kaçırıp tecavüz ettiği yalanında ise fotoğrafa uydurma bir hikaye yazıımıştır. Fotoğraf yolda yüzüstü yatan bir kadını göstermektedir. Erkek şiddetinin mağduru olan kadın görüntüsünün medyada temsili zaten sorunlu olmakla birlikte, bu fotoğraf aslında 2013 yılında gerçekleşen başka bir olayı göstermektedir. Bu içerik, habermiş gibi kurgulanarak gerçeklik etkisi oluşturulmaya çalışılmıştır. Söz dizimi ve kelime seçimi, mağdura uydurma bir isim verilmesi ve katillerin tutuklandığı bilgisinin eklenmesi, metnin gerçeklik etkisini artırmaya yöneliktir. Suriyelilerin Türkiye'ye gelen Afgan mültecileri protesto ettiği iddiasına dayanak olarak kullanılan görüntü, dijital olarak müdahale edilmiş bir fotoğraftır. Fotoğraf aslında 2015 yılında Gaziantep'te, Rusya'nın Suriye'ye müdahalesini protesto eden Suriyelileri göstermektedir. Ancak fotoğraftaki kişilerin ellerinde tuttukları dövizlerdeki cümleler dijital ortamda silinmiş, yerine "AFGAN GO HOME", "Türkiya'da Afganli Göçman İstemiyorız" ifadeleri yazılmıştır.

Bu noktada vurgulanması gereken kritik unsur, kullanıcı türevli içeriklerdeki ayrımcı ve dışlayıcı yönelimin kendiliğinden oluşmadığıdır. Yaygın medyada üretilen, yalan haber kategorisine girmese bile, ayrımcı ve dışlayıcı söylemleri yeniden üretip pekiştiren haberler ve fikir yazıları, dezenformasyonun türediği ve inandırıcı bulunabildiği gerçeklik evrenini yaratmakta pay sahibidirler. Teun van 
Dijk (1991, s. 238), gündelik yaşamda etnik sorunlara ilişkin yaygın düşünme kaııplarının kendiliğinden gelişmediğini, bilhassa medyanın ürettiği ideolojik çerçevelerin bunda önemli bir payı olduğunu savunur. 2011 yılının Nisan ayından 2014 yılının sonuna kadar Zaman, Posta ve Hürriyet gazetelerinde Suriyeli mültecilerle ilgili 1022 haberi analiz eden Ülkü Doğanay ve Hatice Çoban Keneş (2016, s. 145), bu haberlerin Suriyeli mültecilerin "güvenlik tehdidi, ekonomik bir yük ya da kendilerine 'kucak açan'lara ihanet eden 'yabancılar' olarak algılanmasına aracılık ettiği"ni ortaya koymuşlardır. Ayrımcı söylemin kurulmasında ve bu söylemin rasyonelleştirilmesinde ekonomik gerekçelerin önemli bir yer tuttuğunu belirten Doğanay ve Çoban Keneş, Suriyeli mültecilere bu türde imtiyazlar tanındığı yönündeki iddia ve imalarının inceledikleri haberlerde yer aldığını bulgulamışlardır. Örneğin Posta gazetesinin 14 Mayıs 2012 tarihli "Suriyeli mültecilere kredi kartı" haberinin içeriğinde bunun bir iddia olduğuna yer verilmiş olsa da haber başlığında tırnak işareti kullanılmayarak bu iddia bir gerçeklikmiş gibi sunulmuştur. Posta gazetesinin 22 Eylül 2012 tarihli "Mülteciler üniversitelere sınavsız ve belgesiz girecek" haberinde ise yine asılsız iddialar gerçeklikmiş gibi sunulmuştur (Doğanay ve Çoban Keneş, 2016, s. 159, 161, 180). Öte yandan kullanıcı türevli haber benzeri içeriklerde olduğu gibi haber söyleminde de Suriyeli mültecilerin Türkiye için bir güvenlik tehdidi oluşturduğuna ilişkin iddialar belirgin bir yer işgal etmektedir. Mültecilerin haber başlıklarına "kendisine karşı yapılan iyiliğe karşı nankör; gaspçı; dolandırıcı; saldırgan; tecavüzcü" gibi ifadelerle taşındığını gösteren Doğanay ve Çoban Keneş bu kişilerin haberlerde birer tehdit unsuru olarak kriminalize edildiklerini vurgulamışlardır. Örneğin 1 Mayıs 2014 tarihinde Zaman gazetesinde yayınlanan "Sadece fuhuş değil organ ve çocuk mafyası da var" haberi, Suriyeli mültecileri TC vatandaşlarının can ve mal güvenliğine tehdit olarak göstermektedir (Doğanay ve Çoban Keneş, 2016, s. 163, 168). Yaygın medyada üretilen bu haberle, Suriye'de organ mafyasının çocukları kaçırdığı iddiasıyla sosyal medyada dolaşıma giren kullanıcı türevli içeriğin taşıdığı ifadesel ortaklık dikkat çekicidir. Kısaca, 2011-2014 arasında yapılan haberlerdeki gerçekliğe ilişkin söylemlerle, 2017-2018 yıllarındaki yalan haberlerin düzmece gerçekliği birbirleriyle örtüşür niteliktedir. Bu nedenle kullanıcı türevli haber benzeri içeriklerin ürettiği dezenformasyon ile yaygın medyanın ürettiği haberler arasında güçlü bir bağlantı olduğunu; bir başka deyişle, kullanıcı türevli içeriklerin yarattığı düzmece gerçeklik evreninin, yaygın medyanın ayrımcı ve dışlayıcı habercilik pratiğine öykünerek, onu taklit ederek meşruiyet elde ettiğini söyleyebiliriz.

Hakan Ataman (2014) ulusal ve yerel basında Suriyeli mültecilere yönelik ayrımcı söylemi ele aldığı yazısında, Suriyeli mültecilerin hak sahibi özneler olarak görülmediğini, haberler ve köşe yazılarının büyük ölçüde hak temelli bir bakış açısından yoksun olduğunu; Suriyeli mültecilerin güvenlik sorunu olarak görüldüklerini ve haberlerin ötekileştirici söylemi yeniden ürettiğini ortaya koymuştur. Ataman'ın yaptığı araştırmaya göre, hak temelli bakış açısından yoksun söylemlerde, Suriyeli mülteciler cinayet, fuhuş ve dilencilik gibi eylemlerle anılmakta, kiraların ve işsizliğin artışından sorumlu tutulmaktadır (Ataman, 2014, s. 62, 105). Daha yakın tarihte, 2018 yılı Ocak-Nisan ayları arasındaki dört aylık dönemi kapsa- 
yan Medyada Nefret Söylemi İzleme Raporu'nda (2018) ulusal ve yerel basında yer alan haber ve köşe yazılarının 274'ünde Suriyeli mültecilere yönelik nefret söylemi bulunduğu tespit edilmiştir. Raporda Suriyeli mültecilerin "sistematik olarak cinayet, hırsızlık, taciz gibi adli olaylarla anıldı[kları] ve böylece potansiyel suçlu olarak kodlandı[kları]"; "güvenlik sorunları ve "terör'le özdeşleştirildi[kleri]"; "'Zeytin Dalı Harekâtı'na ilişkin haber ve köşe yazılarında Türkiye'deki varlıklarından dolayı hedef gösterildi[kleri]" ve "Türkiye'nin demografik yapısına yönelik bir 'tehdit', genel bir rahatsızlık ve 'gerginlik' kaynağı olarak etiketlendi[kleri]" ortaya konulmuştur (Medyada Nefret Söylemi İzleme Raporu, 2018, s. 5-6).

2011-2018 yılları arasındaki haber ve fikir yazılarının incelenmesine dayalı yukarıdaki araştırma ve raporlar, pek çok toplumsal sorun etrafında öbeklenen medya metinlerinde Suriyeli mültecilerin kategorik bir ötekileştirilmeye maruz kaldıklarını göstermektedir. Her tür toplumsal kötülükle işaretlenerek hak öznesi olmaktan alıkonulmak istenen mülteciler hakkındaki düzmece iddialar, sosyal medyada dolaşıma giren tekil içerikler bazında sayıca düşük görünmekle birlikte, yeniden paylaşımlar yüz binleri, tıklanma sayıları milyonları bulmaktadır. Bir tarafta yabancı düşmanlığının ve ayrımcılığın gündelik hayata giderek daha fazla sızması bu tür haberlerin gerçek olarak kabul edilip kolayca yayılabilmesini sağlamakta, diğer yandan post-hakikat siyasetini elverişli bir taktik olarak benimseyenler, her şeyin sorumlusu yeni düşmanlar icat ederek, yurttaşların sorunlara olguların değil, nefret duygularının gözlüğünden bakmalarını talep etmektedirler. Bu nedenle Suriyeli mültecilerle ilgili yaygın düşünme biçimleri, yalanın gerçeği alt etmesiyle gelişip serpilen bir siyasal hakimiyet mücadelesi içinde şekil almaktadır.

\section{Sonuç}

Post-hakikat kavramının ağırıklı bir yer tuttuğu güncel siyasal eğilimlere ilişkin tartışmalar, gazeteciliğin süregiden krizinin yalnızca teknolojik ve ekonomik koşullardaki değişimle ilişkili olmadığını bize hatırlatır. Toplumsal meşruiyetini hakikat arayışı üzerine inşa eden profesyonel gazetecilik alanı, bu arayışın salt retorik bir motifle sınırlı kaldığı yönündeki eleştirilerden kendisini hiç bir zaman kurtaramamış olsa da, artık yarışan hakikat iddialarının değil, hakikati by-pass etmeye dönük siyasal taktiklerin iş başında olduğu bir evreye girmiş görünmektedir.

Yalan haber tartışmalarının yeniden güncellik kazanması bu nedenle dikkat çekici bir gelişmedir. Bilhassa sağ kanat popülist hareketler, olguları itibarsız kılarak siyasetin zeminini inanç ve duygulara kaydırma çabalarında, yalan haberlere stratejik bir rol atfetmektedir. Öte yandan, popülizmin öfke siyasetinin, olgusal gerçeklik ve rasyonellik iddialarını felce uğrattığı bu siyasal koşullar altında, haber medyasının toplumsal sorumluluğunun çok daha kritik bir beklentiye dönüştüğünü söyleyebiliriz. Gerçek ile gerçek olmayan arasındaki sınırın belirsizleştirilmesi, siyasal söylemlerin ötesine geçip toplumsal iletişimin gerçekleştiği her tür kanala sızdığında, yurttaşlar olup bitenlerle ilgili rasyonel kanaat oluşturabilme çabalarında yalnız kalmaktadır. Gerek profesyonel haber kuruluşlarının ürettikleri yalan 
haberlerin dijital ağlarda hızla dolaşıma girip yaygınlaşması gerekse de kullanıcı türevli içeriklerin yeni medya ekolojisinin içsel bir bileşeni haline gelmesi haberin güvenilirliği sorununu daha karmaşık bir yapıya büründürmektedir. Bu bakımdan yalan haber sorununu, Türkiye'den ve dünyadan tarihsel ve güncel örneklerle ortaya koyduğumuz gibi, kolayca medya kullanıcılarının eleştirel farkındalık eksikliğiyle açıklayamayacağımızı, yalan haber üretme pratiğinin koşullarını belirleyen ideolojik eğilimlerin gücünü ve yurttaşların bu eğilimlerle ilişkilenme biçimlerini doğru tespit etmek gerektiğini düşünüyoruz.

\section{Kaynakça}

Allcott, H. ve Gentzkow, M. (2017). Social Media and Fake News in the 2016 Election. Journal of Economic Perspectives, 31(2), 211-236.

Arabacı, A. O. (18 Ağustos 2017). 131 bin 746 Suriyeli'nin üniversiteye yerleştirildiği iddiası. Erişim 17 Şubat 2018, https://teyit.org/131-bin-746-suriyelinin-universiteye-yerlestirildigi-iddiasi/

Ataman, H. (2014). Yazılı Basında Ayrımcı Söylem, Suriyeli Mülteciler. Medyada Nefret Söylemi ve Ayrımcı Dil Eylül-Aralık 2014 Raporu içinde. İstanbul: Hrant Dink Vakfı. Erişim 8 Ağustos 2018, https://hrantdink.org/attachments/article/91/ EylulAralik2014raporuson.pdf

Barthes, R. (2003). Rhetoric of the Image. L. Wells, (Ed.), The Photography Reader içinde (114-125). New York: Routledge.

Cantril, H. (1940). The Invasion from Mars: A Study in the Psychology of Panic. Princeton, NJ: Princeton University Press.

Çakır, E. (13 Haziran 2013). Kadınlar küfrediyor, erkekler vuruyordu. Star. Erişim 11 Eylül 2018, http://gazete.netgazete.com/gazeteler_arsiv.php

Çavuş, G. (15 Mayıs 2017). Suriye'de organ mafyasının çocukları kaçırdığını gösteren video iddiası. Erişim 11 Mart 2018, https://teyit.org/suriyede-organ-mafyasinin-cocuklari-kacirdigini-gosteren-video-iddiasi/

Çavuş, G. (9 Eylül 2017). İki Suriyelinin Bursa'da bir kadını kaçırıp tecavüz ettiği iddiası. Erişim 11 Mart 2018, https://teyit.org/iki-suriyelinin-bursada-bir-kadini-kacirip-tecavuz-ettigi-iddiasi/

Çavuş, G. (12 Eylül 2017). Suriyeli bir sığınmacının doktor dövdüğü iddiasıyla paylaşılan video Rusya'dan. Erişim 11 Mart 2018, https://teyit.org/suriyeli-bir-siginmacinin-doktor-dovdugu-iddiasiyla-paylasilan-video-rusyadan/

Çavuş, G. (11 Nisan 2018). Fotoğrafın Suriyelilerin Türkiye'ye gelen Afganları protesto ettiğini gösterdiği iddiası. Erişim 18 Nisan 2018, https://teyit.org/fotografin-suriyelilerin-turkiyeye-gelen-afganlari-protesto-ettigini-gosterdigi-iddiasi/

Dahlgren, P. (2018). Media, Knowledge and Trust: The Deepening Epistemic Crisis of Democracy. Javnost-The Public, 25(1-2), 20-27. 
Doğanay, Ü. ve Çoban Keneş, H. (2016). Yazılı Basında Suriyeli 'Mülteciler': Ayrımcı Söylemlerin Rasyonel ve Duygusal Gerekçelerinin İnşası. Mülkiye Dergisi, 40(1), 143-184.

Farkas, J. ve Schou J. (2018). Fake News as a Floating Signifier: Hegemony, Antagonism and the Politics of Falsehood. Javnost-The Public, 25(3), 298-314.

Ferrara, E., Varol, O., Davis, C., Menczer, F. ve Flammini, A. (2016). The Rise of Social Bots. Communications of ACM, 59(7), 96-104.

Fineman, M. (2012). Faking It: Manipulated Photography before Photoshop. New York: Metropolitan Museum of Art.

Fletcher, R. (2018). Misinformation and Disinformation Unpacked. N. Newman vd., (ed.), Reuters Institute Digital News Report 2018 içinde (37-41). Erişim 28 Temmuz 2018, https://Reutersinstitute.politics.ox.ac.uk/sites/default/files/digital-news-report-2018.pdf

Foça, M. A. (28 Mart 2017). Gaziantep'te Suriyeliler vatandaşlık için kuyruğa girdi iddiası. Erişim 11 Mart 2018, https://teyit.org/gaziantepte-suriyeliler-vatandaslik-icin-kuyruga-girdi-iddiasi/

Foça, M. A. (25 Ağustos 2017). Bursa'da yaşayan Suriyelilerin bir atı kafasına vurarak öldürdüğü iddiası. Erişim 11 Mart 2018, https://teyit.org/bursada-yasayan-suriyelilerin-bir-ati-kafasina-vurarak-oldurdugu-iddiasi/

Garimella, K., Morales, G. F, Gionis, A. ve Mathioudakis, M. (2018). Political Discourse on Social Media: Echo Chambers, Gatekeepers, and the Price of Bipartisanship. WWW 2018: The 2018 Web Conference. 23-27 Nisan 2018, Lyon, Fransa.

Gazeteciler 'Kabataş Olayı' Hakkında Konuştu. (15 Şubat 2014). TimeTürk. Erişim 3 Eylül 2018, https://www.timeturk.com/tr/2014/02/15/elif-cakir-dan-kabatas-aciklamasi.html\#.

Hirst, M. (2011). News 2.0: Can Journalism Survive the Internet? New South Wales: Allen and Unvin.

Hirst, M. (2017). Towards a Political Economy of Fake News. The Political Economy of Communication, 5(2), 82-94.

Ji, Q., Ha, L. ve Sypher, U. (2014). The Role of News Media Use and Demographic Characteristics in the Possibility of Information Overload Prediction. International Journal of Communication, 8, 699-714.

Kıvanç, Ü. (16 Şubat 2014). Kabataş meselesi/2 - Sis, pus, hamaset arasından... Erişim 1 Eylül 2018, http://riyatabirleri.blogspot.com/2014/02/kabatas-olay-sis-pus-hamaset-arasndan.html

Kuçuradi, I. (2009). Felsefi Etik ve Meslek Etikleri. H. Tepe, (Yay. Haz.), Etik ve Meslek Etikleri içinde (27-43). Ankara: Felsefe Kurumu Yayınları. 
Lievrouw, L. H. (2010). Social Media and the Production of Knowledge: A Return to Little Science? Social Epistemology, 24(3), 219-237.

Lister, M., Dovey, J., Giddings, S., Grant, I. ve Kelly, K. (2009). New Media: A Critical Introduction. New York: Routledge.

Livingstone, S. (2004). Media Literacy and the Challenge of New Information and Communication Technologies. The Communication Review, 7(1), 3-14.

Machin, D. (2007). Introduction to Multimodal Analysis. Londra ve New York: Bloomsbury.

Martin, N. (2017). Journalism, the Pressures of Verification and Notions of PostTruth in Civil Society. Cosmopolitan Civil Societies: An Interdisciplinary Journal, 9(2), 41-55.

Mclntyre, L. (2018). Post-Truth. Massachusetts: The MIT Press.

Medyada Nefret Söylemi İzleme Raporu (2018). Erişim 12 Ağustos 2018, https:// hrantdink.org/attachments/article/1356/Medyada\%20Nefret\%20Söylemi\%20izleme\%20Raporu\%200cak-Nisan\%202018.pdf

Newman, N., Dutton, W. H. ve Blank (2012). Social Media in the Changing Ecology of News: The Fourth and Fifth Estates in Britain. International Journal of Internet Science, 7(1), 6-22.

Newman, N., Fletcher, R., Kalogeropoulos, A., Levy, D. A. L. ve Kleis, Rasmus (2018). Reuters Institute Digital News Report 2018. Erişim 30 Temmuz 2018, https://Reutersinstitute.politics.ox.ac.uk/sites/default/files/digital-news-report-2018.pdf

Özer, Ç. L. (07 Şubat 2017). Suriyelilere alışverişlerde yüzde 50 indirim sağlayan Ak Kart verildi iddiası. 11 Mart 2018, https://teyit.org/suriyelilere-alisverislerde-yuzde-50-indirim-saglayan-ak-kart-verildi-iddiasi/

Özer, Ç. L. (14 Şubat 2017). Konya Büyükşehir Belediyesi Suriyelilere maaş bağladı iddiası. 11 Mart 2018, https://teyit.org/konya-buyuksehir-belediyesi-suriyelilere-maas-bagladi-iddiasi/

Özer, Ç. L. (06 Mart 2017). Suriyeliler istedikleri üniversiteye hiçbir koşul olmadan girebiliyor iddiası. 11 Mart 2018, https://teyit.org/suriyeliler-universiteye-kosulsuz-sinavsiz-girebiliyor-iddiasi/

Özer, Ç. L. (09 Mart 2017). Suriyeliler maaşlarını almak için PTT önünde kuyruğa giriyor iddiası. 11 Mart 2018, https://teyit.org/suriyeliler-maaslarini-almak-icin-ptt-onunde-kuyruga-giriyor-iddiasi/

Özer, Ç. L. (09 Haziran 2017). Suriyeliler, Türkiye halkının dinden kopuk yaşadığını söyleyerek yürüyüş düzenledi iddiası. Erişim 11 Mart 2018, https://teyit.org/suriyeliler-turkiye-halkinin-dinden-kopuk-yasadigi-iddiasiyla-yuruyus-duzenledi-iddiasi/

Paltridge, B. (2012). Discourse Analysis: An Introduction. Londra ve New York: 
Bloomsbury.

Reuters Toughens Rules After Altered Photo Affair. (21.01.2007). Reuters. Erişim 10 Temmuz 2017. https://www.Reuters.com/article/idUSL18678707

Scannell, P. (2007). Media and Communication. Londra: Sage.

Schudson, M. (1978). Discovering the News: A Social History of American Journalism. New York: Basic Books.

Selvi, A. (12 Haziran 2013). Başbakan'ın Sözünü Ettiği Gelin. Yeni Şafak. Erişim: 11 Eylül 2018, https://www.yenisafak.com/yazarlar/abdulkadirselvi/babakanin-sozunu-ettigi-gelin-38114

Shao, C.; Ciampaglia, G. L.; Varol, O.; Flammini, A. ve Menczer, F. (2017). The Spread of Fake News by Social Bots. Erişim 26 Temmuz 2018, eprint arXiv:1707.07592 https://andyblackassociates.co.uk/wp-content/uploads/2015/06/fakenewsbots. pdf

Shu, K.; Sliva, A.; Wang, S.; Tang, J. ve Liu, H. (2017). Fake News Detection on Social Media: A Data Mining Perspective. SIGKDD Explorations, 19(1), 22-36.

Sunstein, C. R. (2018). \#Republic: Divided Democracy in the Age of Social Media. New Jersey: Princeton University Press.

Tandoc, E., Lim, Z. W. ve Ling R. (2017). Defining 'Fake News': A Typology of Scholarly Definitions. Digital Journalism, 6(2), 137-153.

Türkiye'de yaşayan Suriyelilerle ilgili internette yayılan 14 yanlış bilgi. (21.09.2017). Erişim 3 Ağustos 2018, https://teyit.org/turkiyede-yasayan-suriyelilerle-ilgili-internette-yayilan-14-yanlis-bilgi/

Yeşil, B. (2016). Media in New Turkey: The Origins of an Authoritarian Neoliberal State. Urbana: University of Illinois Press.

van Leeuwen, T. (2004). Semiotics and Iconography. T. van Leeuwen ve C. Jewitt, (ed.), Handbook of Visual Analysis içinde (92-118). Londra: Sage.

van Leeuwen, T. (2011). Multimodality and Multimodal Research. E. Margolis ve L. Pauwels, (ed.), The Sage Handbook of Visual Research Methods içinde (549570). Londra: Sage.

van Djik, T. (1991). Racism and the Press. Londra: Routledge.

Wardle, C. (2017). "Fake news. It's complicated." First Draft. Erişim 5 Temmuz 2018 https://medium.com/1 st-draft/fake-news-its-complicated-d0f773766c79.

White, A. (2017). Fake News: Facebook and Matters of Fact in the Post-Truth Era. A. White, (ed.), Ethics in the News: EJN Report on Challenges for Journalism in the Post-truth Era içinde (14-17). Londra: Ethical Journalism Network. 
